\title{
Against empathy \\ voice and authenticity
}

Af Patti Lather

Skal de udforskede have stemme, autenticitet og stemme? Er det forskeren, der $i$ sidste ende er den, der ved? Skal en videnskabelig tekst vare klar, entydig og samarbejdsvillig? Nej, skriver Patti Lather, let's get lost!

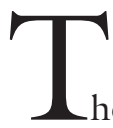

he demand for

feminist research to be centered by such concepts as "empathy," "voice" and "authenticity" has been central for the movement away from scientistic thought. This demand is much troubled by critiques of the coherent subject that presuppose the subject who speaks for themselves; the subject capable of knowing others; and the subject in charge of their desires and identifications. This article presents a genealogy of knowing as narration and representation of the other based on comfortable and comforting, empathetic, mutual, dialogical knowing, critiquing such knowledge practices as violence, as imperial sameness once again. It asks, what is it to claim voice, authenticity and empathy as the grounds of research? Can there be a research that refuses such grounds, residing in messy "spaces in between" (Robinson 1994) where centers and margins are both situated and yet constantly changing intersections of interpretation, interruption and mutuality? 
To explore the contemporary demands for feminist research to be a space where the researcher practices empathy and offers or facilitates the voice of the researched and the researcher toward more "authentic" knowing, I make three moves. First, I unpack poststructuralism in order to challenge the typical investments and categories of ethnography so as to put under theoretic pressure the claims of scientificity. I do so via a move away from what Britzman (1997) refers to as the wish for heroism and rescue through some "more adequate" methodology and toward a learning that can tolerate its own failure of knowledge and the detour of not understanding. Secondly, grounded in my "postbook" thinking, , I trouble the ethnographer as "the one who knows" whose task is to produce the persuasive text that elicits reader empathy, in this case, for women living with $\mathrm{HIV} / \mathrm{AIDS}$. Finally, I probe what is at work in the concepts of "voice" and "authenticity" in ethnographic work.

\section{AgAinst SCIENTIFICITY:}

A (GAY) SCIENCE “AFTER TRUTH”

Stanley Aronowitz (1995) defines scientificity as not so much the actual practices of science as "the permeation of the standard elements of the scientific attitude into all corners of the social world: seeing is believing; the appeal to 'hard facts' such as statistical outcomes to settle arguments; the ineluctable faith in the elements of syllogistic reasoning" (12). Poststructuralism troubles the foundational knowledges that undergird such claims (Hollinger 1994; Haraway 1997).

What do we speak of when we speak of a poststructural science? Rather than heroism or rescue through some new methodology, Britzman (1997) argues that we may be in a time and place where we are better served by research if it is a means to see the need to be wounded by thought as an ethical move. "Incited by the demand for voice and situatedness" (31), she writes about the curious history of research's mistaken identities. How do we come to think of things this way, she asks, and what would be made possible if we were to think research otherwise, as a space surprised by difference into the performance of practices of not-knowing.

The theoretical and methodological competitiveness of "successor regimes" (Harding 1991) that continues to characterize social inquiry often positions qualitative research as some sort of savior. To the contrary, Britzman (1997) points out that qualitative research is filled with sacred objects to be recovered, restored, centered. There is a tendency to avoid the difficult story, to want to restore the good name of research with these "new" and "better" methods. But research "can't seem to get it right" (35), and, she writes, too often our efforts fall back into the too easy to tell story of salvation via one sort of knowledge practice or another. As Britzman goes on to note, what is at stake when research is at stake is whether research can be a mode of thought that refuses to secure itself with the consolations of foundationalism and nostalgia for presence, the lost object of correct knowledge, the security of understanding. This is a move out of the sort of "devotional scientism" that underwrites the Christian-capitalist-industrialist creed and toward what Nietzsche (1974) termed a "gay science," a science based in the very splintering of the mechanisms of control and the resultant incredulity about salvation narratives of scientific progress, reason and the over administered world. Hence, my argument is that the research of most use is that which addresses how knowledge remains possible given the end of the value free notion of science and the resultant troubling of confidence in the scientific project, a science "after truth" (Tomlinson 1989). To explore what such a practice might look like, I turn to Chris and my efforts in our book on women living with HIV/AIDS. 


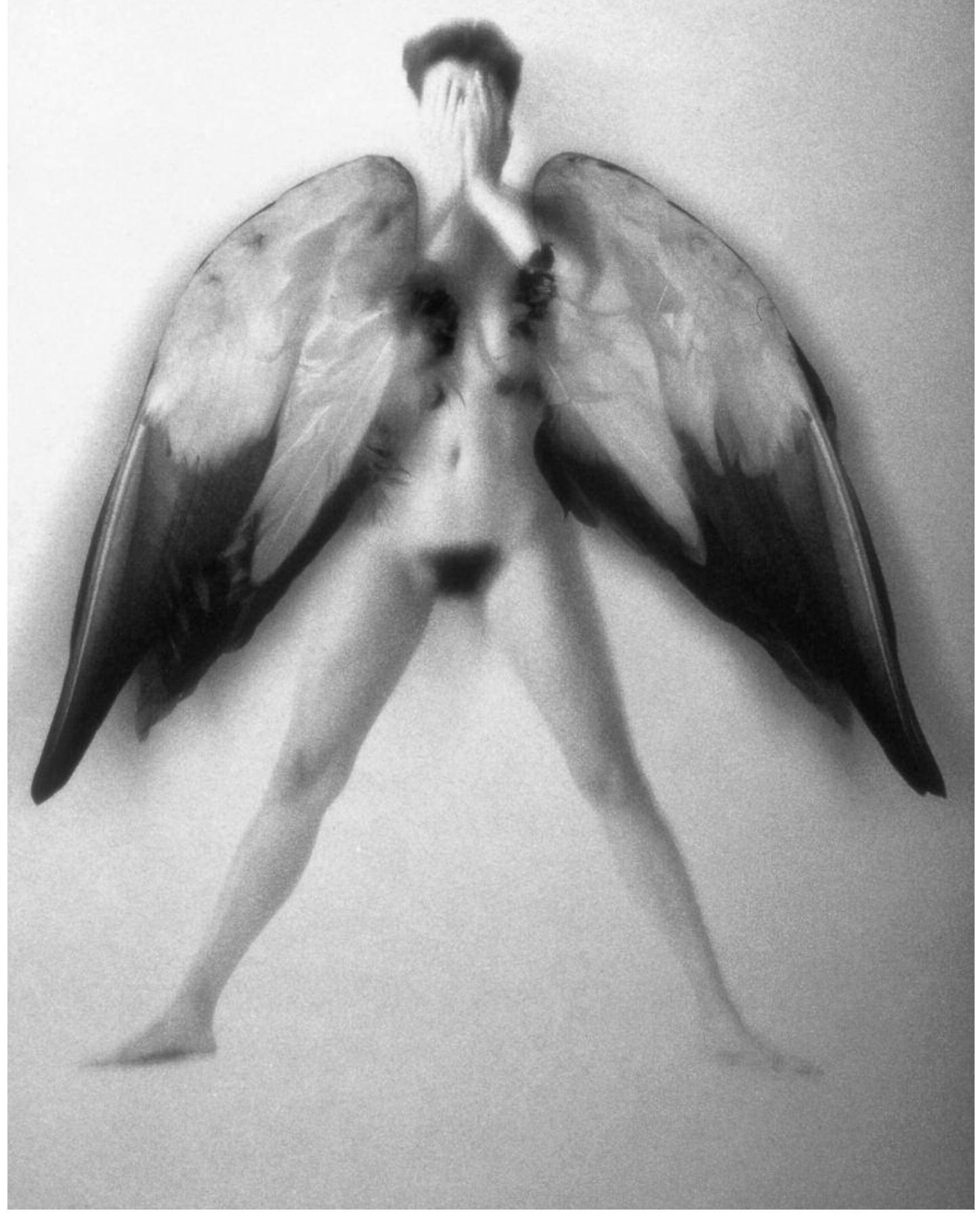

Foto: Will Shively, AIDS Angel I, 1994. Gengivet med kunstnerens venlige tilladelse. 
AgAINST EMPATHY:

A METHODOLOGY OF GETTING LOST

Western feminist ethnographic traditions of romantic aspirations about giving voice to the voiceless are much troubled in the face of the manipulation, violation and betrayal inherent in ethnographic representation (Visweswaran 1994). At the limits of intelligibility, Troubling the Angels works across various layers and shifts of register in order to construct an audience with ears to hear. This was Chris and my task as we live out the ambivalent failure of the uses of research toward something more productive of an enabling violation of its disciplining effects. Inhabiting the practices of its rearticulation, "citing, twisting, queering," to use Judith Butler's words (1993b, 237), we occupy the very space opened up by the ruins of the concept of ethnographic representation.

"The too easy to tell tale" (Britzman 1998) would have delivered the women to the reader in a linear, tidy narrative. Instead, refusing easy identifications, the reader comes to know through a form of textual dispersal of discontinuous bits and multiples of the women's stories. Thus the text works to elicit an experience of the women through the very failures of the book to represent them in order to set up a different economy of exchange that interrupts voyeurism and the erasure of difference.

AIDS activist and theorist, Douglas Crimp (Caruth and Keenan 1995), argues that the sort of empathetic understanding evoked by Kimberly Bergalis gets constructed in relation to sameness. Empathy, then, actually "solidifies the structure of discrimination" (264) and diffuses any confrontation with death. Similarly, Elizabeth Ellsworth (1997) speaks against empathy as "the beautiful fit." Instead, she advocates counter-practices of queering, disidentifying, denaturalizing, defamiliarizing: producing difference instead of the same. Reading for some empathic union of two selves in a mirroring relationship is NOT helpful in unfixing categories. Instead, Ellsworth argues, we need to act from the abject space of the between, to make that space material so that we keep it unsettled. Here, our task is to not remain within the same logic of identity and difference from which we presume to escape. Rather, the task is to produce processes and movements beyond the fixedness, or limited mobility of presently conceptualized categories of difference.

In Deleuzean language, this is not about empathy so much as becoming (Deleuze and Guattari 1983). To argue against empathy is to trouble the possibilities of understanding, as premised on structures that all people share. The issue is the limitations of cognitive access to other individuals and what one can experience of another, "the riddle of intersubjectivity" (Sawicki 1997, 126). It is also about audiences and issues of resisting competent readers and intentionality, some rhetoric outside of persuasion, some focus on what we cannot know, a move away from fantasies of mutuality, shared experience, and touristic invitations to intimacy.

In a book less argued than enacted, Chris and I have written an "uncooperative text" that refuses mimentic desire and reader entitlement to know. It constructs a distance between reader and subject of the research, producing a kind of gap between text and reader. Refusing the liberal embrace of empathy that reduces otherness to sameness within a personalized culture, declining the too easy to possess knowledge and casting doubt on our capacity to know, it refuses the mutuality and dialogue that typify an empathetic approach to understanding.

As Sommer (1994) notes, these points are double, both epistemological and ethical. They are about what we can know but also what we, perhaps, ought not to assume we have the right to know. What Sommer terms a recalcitrant rather than a persuasive rhetoric questions enlightenment views of 
understanding as necessarily liberating (542). Forcing understandable identities, overlooking differences "for the sake of a comforting, self-justifying rush of identification," the will to understand the Other is therefore a kind of violence, "an appropriation in the guise of an embrace" (543). This is how empathy violates the other and is part of the demand for totality. A recalcitrant rhetoric is about inaccessible alterity, a lesson in modesty and respect, somewhere outside of our desire to possess, know, grasp. Here, "interpretive reticence" makes sense (548) as we learn to listen to what the Other has to say without the mutuality presumed by empathy. To withold the anticipated intimacy that invites conquest, teaching the reader how to read at some distance, with respect for the distances: this is the readerly response our text tries to constitute, a defiant book that teaches unanticipated lessons by being "hard to read." 2

Defying our personalized culture, easy identifications, and sentimentalizing empathy, this argument foregrounds the inadequacies of thought to its object. Empathy is situated in relation to sameness and "solidifies the structure of discrimination" (Caruth and Keenan 1995, 264). Denying the "comfort text" in moving away from fantasies of mutuality, shared experience, dialogue and touristic invitations to intimacy, the book declines the too easy to possess knowledge and reader entitlement to know.

\section{Against VOICE AND AUTHENTICITY: REPRESENTATION AND THE NEW EHTNOGRAPHY}

Questions of authenticity and voice are at the heart of claims to the "real" in ethnography. Indeed, in the "new" ethnography, that which comes after the crisis of representation (Marcus and Fischer 1986), the authority of voice is often privileged over other analyses. Confessional tales, authorial self-revelation, multivoicedness and personal narrative, all are contemporary practices of representation designed to move ethnography away from scientificity and the appropriation of others. At risk is a romance of the speaking subject and a metaphysics of presence that threaten to collapse ethnography under the weight of circumscribed modes of identity, intentionality and selective appropriation (Atkinson and Silverman 1997; Hargreaves 19963).

But one example is The Education of Little Tree (1976), a so-called autobiography by "Forrest Carter." 4 In writing of authenticity and voice in his discussion of Carter's fraud, Henry Louis Gates (1991) castigates "the ideologues of authenticity" (2) and explores concepts of true lies, pseudoslave narratives, "the real black writer," the authority of experience in policing genre boundaries, ${ }^{5}$ and the intertextuality of Uncle Tom's Cabin where slave narratives were influenced by Stowe and Stowe by slave narratives. The key, Gates argues, is to see "the troublesome role of authenticity" (2) as linked to "imputations of realness" that elide how, while identity indeed matters, "all writers are "cultural impersonators"' (3). Whatever it means for a writer to speak “"as-a," (Miller, quoted in Gates 1991, 4), authenticity is much more complicated than singular, transparent, static identity categories assumed to give the writer a particular view.

Given such complications, how are we to think of the problematics of 'authenticity'? "Heidegger instituted authenticity," Adorno argues $(1973,17)$, disparagingly, at least in its second generation which betrayed Kierkegaard and Nietzsche in its systematic ontologizing of authenticity as a philosophical concept (Golomb 1995). To read Heidegger most generously, invested in displacing the dominance of the subject in thought and language, Heidegger's effort was to think in the question of authenticity and voice, turning the question, "thinking in an aporia" (Scott 1996, 84) of the question. While getting lost is set up as some other to "homing in on our being" (Ibid, 16), it 
is Heidegger that thinks the thought of a tradition beginning to overturn itself within itself, in this case, a move away from transcendence or, perhaps better said, a thinking within the aporia of the loss of transcendence. ${ }^{6}$

Less generously, Adorno (1973) situates the "cult of authenticity" (5) as an existential jargon that is part of the disintegration of aura. Creating a universal that must be negated if we are to escape the "liturgy of inwardness" (70) and quest for pure identity that "devours everything" (139), Adorno's disdain for Heidegger follows that of his mentor, Walter Benjamin. Benjamin's interest was the loss of "aura" versus Heidegger's search for fullness of essence (Golomb 1995). For Benjamin, what mattered was how to work the ruins of aura toward a living on. The loss of aura was the loss of transcendence under conditions of history as a permanent emergency. Trying to gather the weak messianic power of those who have been passed over by history, Benjamin $(1939 / 1968)$ worked the ruins of theology to ask just how secular are our supposedly non-theistic forms of thought. The secularized discourse of post-Kantian modernity is not as different from earlier theological discourses as modernists would like to believe-this was Benjamin's turn to theology, against the devaluation of truth in the name of knowledge (Nagele 1991). To get lost at the limits of representation is to encounter the radical discontinuity of modernism and the secularization that is its basis. This is about the limits of knowledge where the old significance is shattered, "but the signifiers resist, empty shells for somber ghosts" (Ibid., 195).

In Troubling the Angels, the angels circulate among many questions, sharpening problems, making insufficiencies pressing, and marking the limits of any easy resolutions of issues around voice and authenticity. "Trying", as Derrida cautions, "not to take advantage of the emotion" (1996, 185), Chris and I mobilized the angel to use sen- timentality against itself and construct a questioning text that signals tentativeness and partiality. The angel, then, is a placeholder, a shell for the ghost of meaning. Our recourse to an old theological symbol insists on the otherness that remains outside of any reconciliation. Like Benjamin's Angel of History, the various voices of our text are inverted and perverted, folded and refolded into some non-fixity. This sets up an escape from the general cliches of the Frankfurt School so that thinking might start over about the traces of otherness that cannot be erased by secularization or edified by the self-deceptions of a humanistic rhetoric (Nagele 1991, 53). Hence the angel is the ghost of unassimilable otherness that haunts the house of Reason, self-reflexive subjectivity and historical continuity. Revising constitutive concepts of history and subjectivity, interiority and experience, this is an economy of displacements that condenses something other than individualized and psychologized motivations. Here the angel is an effect/affect that helps organize a less bounded space where we do what we can while leaving a place for what we cannot envision to emerge.

In spite of Frederic Jameson's (1984) claim regarding the waning of affect in postmodernism, a new subjectivity seems part of the landscape that creates a renewed interest in affect, emotional responses, "feelings" (Massumi 1995; Sedgwick 1995). Public discourse is full of first-person voice: AA, therapy, talk show public performance of private pain, affective epidemics of the Right, "moral panics" that occupy pernicious structures of belonging and identification. This turn to affect is complicated by Benjamin's moves against sentimentality and subjectivism. His historical and sociological impulses were toward a non-subjectivist thinking where affect becomes dynamism, complexity, aggregative capacity (Rochlitz 1996).

Spivak (1994) asks how terrifying is this "contamination" of subjectivity against te- 
chnologism and capitalism. This turn to affect (Sedgwick 1995) works the pathos of the ruins (Butler 1993a), what Kathryn Bond Stockton traces as the return of "sentiment and sobs" (1994, xxii). In the age of AIDS, she suggests, "emotional extravagance" might seem fitting to academic cultural critics. As a way to join pubic sentiment, "teasing out sobs" is about learning how to visit loss via a risk of the personal form that is transgressive in its sentiment. Her caution is that such ardor not sacrifice shadow for sense as she endorses a kind of opaque personal confession outside formulas, personal writing that is scandalous, excessive and leaky but based in lack and ruin rather than plenitude. Hence Benjamin's baroque imaginary of ruin and dislocation is useful in situating questions of authenticity and voice, an imaginary that is not about a lost plenitude but about a loss of aura. This is layered with Stockton's evocation of female potential for otherness and transgression and the question of living on, under conditions of the loss of belief in fullness and epistemological certitude.

Within such questions, is Chris and my text symptom or index? Given the frenzy of demands to show emotion, voice is an authorizing disclosure that points to the insufficiencies of our Hegelian inheritance of historical teleology, subject-centered rationality and recuperation of the Other into the Same. In what I have come to call the "validity of tears" in audience reception of our book (Lather 1997), I see a desire for personal revelation that constructs the appearance of authenticity as having much to do with the abjection of theory and the reinscription of presence. To touch something outside the authority of interpretive thought, to speak of, to, with, for and in the place of simultaneously (Derrida 1993) as a way to construct a different relationality: this is the sort of authorial agency in excess of subjectivity and phenomenological apprehension to which Chris and I aspired. But the demand for voice also has much to do with subjugated knowledges and multiple fractured voices, the unheard/unhearable voices of Spivak's (1988) "Can the Subaltern Speak?"

Hence what I attempt here is not so much "against" empathy, voice and authenticity as it is a double economy of the text to counter-balance the leveling effects of assimilation into sameness. As a sort of "pragmatic intervention in the machinery of mimesis" (Cohen 1994, 103), Troubling the Angels uses de-authorizing devices such as shifting counter voices and subtextual under-writing which ruptures the narrative and forces reading in two directions; dialogic openness and variability of meaning that undercut rhetorical strategies that position the authors as "the ones who know"; partiality, chunkiness and deferral rather than depiction to signal that representation is irreducible to the terms of the real; and a refusal of closure that works against ending on the sort of recuperative note typical of "the religious left" (Gilbert-Rolfe 1995, 56).

Perhaps, then, our book is BOTH symptom and index of an effort to rethink science and culture as constituted by difference rather than consensus without resituating Chris and myself as romantic god-artists who create sublime moments of unity and totality. Foregrounding sociology and politics, we situate our textual moves within and against the historical and normative status of the "new" ethnography as we try to not position ourselves as knowing more about these women than they know about themselves. Situating their voices above ours on the split-pages and their poems in boxes out of control by authorial judgment, our aim is not so much verisimilitude as a troubling of authority in the telling of other people's stories. Not at all about avoiding interpretation, the angel inter-texts signal its inevitable weight and the ruins of the author as either priest or prophet. Resisting the unified subject and universal values, the book marks a methodology of 
getting lost and an uneasiness in the quest for a less comfortable social science. ${ }^{7}$

\section{CONCLUSION: \\ INTERPRETATION AND ITS \\ COMPLICITIES}

Grounded in AIDS related testimony by women, I have attempted a counter-discourse to defamiliarize common sentiments of empathy, voice and authenticity. In a book that works hard to interrupt "the simplicity of style and popular appeal” (Mehuron 1997, 167) that readers might expect in research intending to honor those struggling within and against this disease, I situate such efforts as a breaking of the hegemonies of meaning and presence that recuperate and appropriate the tragedies of others into consumption, a too-easy, toofamiliar eating of the other. Against homogeneous spaces of collective consensus and communication, such work is emotive, figurative, inexact, dispersed and deferred in its presentation of truth-telling toward responsibility within indeterminacy.

\section{Noter}

1. Patti Lather and Chris Smithies, Troubling the Angels: Women Living With HIV/AIDS (Westview/HarperCollins, 1997).

2. See Kushner (1997) on the need "to demand something tough of an audience," art that is "antagonistic to our usual consumption patterns." See Alvermann and St. Pierre (1998) for an early report on a study of reading "hard" books.

3. Hargreaves writes, "It is perhaps time to contextualize the study of teachers' voices, knowledge, and experience more, and to romanticize and moralize about teachers' voices in general rather less" $(1996,16)$. Calling unproblematically on empathy and authenticity, Hargreaves' project is not so much to trouble the concept of voice as it is to trouble the over-reliance on teacher voice at the expense of other stakeholders in public schooling.

4. A best-seller, with over 600,000 copies sold, used in myriad multicultural courses as "authentic autobiography," the author of The Education of Little Tree, "Forrest Carter," presenting himself as a Cherokee storyteller, was found to be Asa Earl
Carter, a Ku Klux Klan sympathizer who wrote segregation speeches for governor George Wallace. See Carter, 1991. Thanks to Ingrid Johnston (1997) for reminding me of this.

5. A recent example is The City of Light: An Authentic Traveler's Tale, Jacob d'Ancona, translated by David Selbourne, about twelfth century China, thereby supplanting Marco Polo as the first European account of China. "A clever conceit for a novel," one critic says. "Authentic it is," says another (Newsweek, October 6, 1997, 70).

6. For Heidegger, authenticity is an existence which one makes one's own, "a grasping of one's own existence which gives it direction and meaning" (Piper 1998, 30). To understand our situatedness is to project forward in our history, particularly toward our own death. To be inauthentic is to be lost in the definitions of others, lost in our thrownness. To be authentic is to be about the possible rather than the given, "an ethical desire for a grounding presence" (Scott 1996, 15) that recognizes the importance of dislocation in breaking the hegemonies of meaning and presence. 7. My thinking in this section is inspired by Malini Johar Schueller's 1992 critique of James Agee's Let Us Now Praise Famous Men where she situates Agee as paternalistic and liberal in his idealization of those whose stories he tells but, nevertheless, opening a space for subverting narrow and consensual definitions of the tenant farmers who people his book.

\section{LITTERATUR}

- Adorno, Theodor (1973): The jargon of authenticity, trans. Knut Tarnowski and Frederic Will.

Evanston. Northwestern University Press. - Alvermann, Donna and St. Pierre, Betty (1998): Reading texts that are too hard to read. Paper presented at the annual conference of the International Reading Association Reading Research, Orlando Florida.

- Aronowitz, Stanley (1995): Bringing science and scientificity down to earth, in Cultural Studies Times, 1 (3), 12, 14.

- Atkinson, Paul and David Silverman (1997):

Kundera's Immortality: The interview society and the invention of the self, in Qualitative Inquiry, 3 (3), 304-325.

- Benjamin, Walter (1939/1968): Theses on the philosophy of history, in Illuminations, Hannah Arendt (ed.). Schocken, New York 253-264. - Blanchot, Maurice (1986): The writing of the disaster, trans. Ann Smock. University of NB Press, Lincoln. 
- Britzman, Deborah (1995): "The question of belief": Writing poststructural ethnography, in Qualitative Studies in Education, 8 (3), 229238

- Britzman, Deborah (1997): The tangles of implication, in Qualitative Studies in Education, 10 (1), 31-37.

- Britzman, Deborah (1998): Lost subjects, contested objects: Towards a psychoanalytic inquiry of learning. SUNY Press, Albany New York.

- Butler, Judith (1993a): Poststructuralism and postmarxism, in diacritics, 23 (4), 3-11.

- Butler, Judith (1993b): Bodies that matter. Routledge, New York.

- Butler, Judith (1995): For a careful reading, in S. Benhabib, J. Butler, D. Cornell and N. Fraser (eds.) Feminist contradictions: A philosophical exchange. Routledge, New York, 127-144.

- Carter, Dan (1991): The transformation of a Klansman, in The New York Times, Oct. 4, p. A31. - Caruth, Cathy and Thomas Keenan (1995):

"The AIDS crisis is not over": A conversation with Gregg Bordowitz, Douglas Crimp, and Laura Pinsky, in Trauma: Explorations in memory, C. Caruth (ed.): Johns Hopkins University Press, Baltimore 256-272.

- Cohen, Tom (1994): Anti-mimesis from Plato to Hitchcock. Cambridge University Press.

- Deleuze, Gilles and Felix Guattari (1983): On the line, trans. J. Johnson. Semiotexte, New York.

- Derrida, Jacques (1976): On Grammatology, trans. G. Spivak. Johns Hopkins University Press, Baltimore.

- Derrida, Jacques (1993): Circumfessions, in Jacques Derrida, Geoffrey Bennington and Jacques

Derrida. University of Chicago, Chicago.

- Ellsworth, Elizabeth (1997): The uses of the sublime in teaching difference. Paper delivered at the annual meeting of the American Educational Research Association, Chicago, March 24-28. - Felman, Shoshona and Dori Laub (1992): Testimony: Crises of witnessing literature, psychoanalysis, and history. Routledge, New York.

. Gates, Henry Louis (1991): 'Authenticity,' or the lesson of Little Tree, in New York Times Book Review, Nov. 24, 1991, 1-4.

- Gilbert-Rolfe, Jeremy (1995): Beyond piety: Critical essays on the visual arts, 1986-1993. Cambridge University Press.

- Golomb, Jacob (1995): In search of authenticity: From Kierkegaard to Camus. Routledge, London. - Haraway, Donna (1997): Modest witness@Second millenium: Feminism and technoscience. Routledge, New York.

. Harding, Sandra (1991): Whose science? Whose knowledge? Cornell University Press, Ithaca New York.

- Hargreaves, Andy (1996): Revisiting voice, in Educational Researcher, 25 (1), 12-19.

- Hollinger, Robert (1994): Postmodernism and the social sciences. Sage, Newbury Park.

- Jamison, Frederic (1984): Postmodernism, or the cultural logic of late capitalism, in The New Left Review, 146, 52-92.

- Johnston, Ingrid (1997): Can the non-subaltern speak? Dilemmas of voice and cultural appropriation in literary texts. JCT Conference, Bloomington Indiana.

- Kushner, Tony (1997): The art of the difficult, in Civilization, August/Sept., 62-67.

- Lather, Patti and Chris Smithies (1997): Troubling the angels: Women living with HIV/AIDS.

Westview/HarperCollins, Boulder.

- Lather, Patti (in press): Postbook: Working the ruins of feminist ethnography, in Signs.

- Marcus, George and Michael Fischer (1986): A crisis of representation in the human sciences, in Anthropology as cultural critique: An experimental moment in the human sciences, Marcus and Fischer (eds.) University of Chicago, 7-16.

- Massumi, Brian (1995): The autonomy of affect, in Cultural Critique, 31, 83-109.

- Mehuron, Kate (1997): Sentiment recaptured: The performative in women's AIDS-related testimonies, in Feminist Interpretations of Jacques Derrida, Nancy Holland (ed.) The Penn. State University Press, University Park PA, 165-192.

- Menchu, Rigoberta (1984): I Rigoberta Menchu: An Indian Woman in Guatemala. Verso, London. - Nagele, Rainer (1991): Theatre, theory, speculation: Walter Benjamin and the scenes of modernity. The Johns Hopkins University Press, Baltimore.

- Nietzsche, Frederic (1974): The Gay Science, trans. W. Kaufmann. Vintage, New York.

- Piper, David (1997): Lacan, Heidegger, and the future anterior of teaching and learning, in Journal of Curriculum Theorizing, 13 (3), 28-33.

- Robinson, J. (1994): White women researching/representing "others": From antiapartheid to postcolonialism?, in A. Blunt and G. Rose (eds.) Writing women and space (197-226). Guilford, New York.

- Rochlitz, Rainer (1996): The disenchantment of art: The philosophy of Walter Benjamin. Guilford, New York.

- Sawicki, Marianne (1997): Empathy before and after Husserl, in Philosophy Today, Spring, 123-127. - Schueller, Malini Johar (1992): The politics of voice: Liberalism and social criticism from Franklin to Kingston. SUNY, Albany. 
- Scott, Charles (1996): On the advantages and disadvantages of ethics and politics. Indiana University Press, Bloomington.

- Sedgwick, Eve (1995): Affect, in Critical Inqui$r y, 21,496-522$.

- Sommer, Doris (1994): Resistant texts and incompetent readers, in Poetics Today, 15 (4), 523551 .

- Spivak, Gayatri (1988): Can the subaltern speak?, in Marxism and the interpretation of culture, Cary Nelson and Lawrence Grossberg (eds.) University of Illinois Press, Urbana, 271-313.

- Spivak, Gayatri (1993): Outside in the teaching machine. Routledge, New York.

- Spivak, Gayatri (1994): Responsibility, in boundary 2, 21 (3), 19-64.

- Stockton, Kathryn Bond (1994): God between their lips: Desire between women in Irigaray, Bronte and Eliot. Stanford University Press.

- Visweswaran, Kamala (1994): Fictions of feminist ethnography. University of MN Press, Minneapolis.

\section{SUMMARY}

This paper asks what it is to claim empathy, voice and authenticity as the grounds of feminist research. It explores representational practices that refuse such grounds by residing in both situated and constantly changing intersections of interpretation, interruption and mutuality. The typical investments and categories of ethnography are challenged so as to put under theoretic pressure the claims of scientificity. Grounded in a study of women living with HIV/AIDS, also challenged is the ethnographer as "the one who knows" whose task is to produce the persuasive text the elicits reader empathy. Finally, the paper probes what is at work in the concepts of "voice" and "authenticity” in ethnographic work.

Patti Lather er professor ved Cultural Studies i Education ved School of Educational Policy and Leadership, Ohio State University 